\title{
Effectiveness of Mixed Insecticide Active Material of Buthyl Phenil Methyl Carbamat (BPMC) using Imidaclorofit on Brown Planthopper (Nilavarta lugens) In Lusi Variety Glutinous Rice
}

\author{
Salamet Ginandjar ${ }^{1}$, Muhammad Subandi ${ }^{2}$, Budy Prasetya ${ }^{3}$,Sri Mulyati ${ }^{4}$, Dina Gustiana ${ }^{5}$ \\ \{Salametginandjar@uinsgd.ac.id $\left.{ }^{1}\right\}$ \\ Faculty of Science and Technology, UIN Sunan Gunung Djati Bandung ${ }^{1}$
}

\begin{abstract}
The purposes of this study was to Determine the effectiveness of the test insecticide active ingredient phenil butyl methyl carbamate (BPMC) and imidakloropid against "Brown Planthopper Trunk" (Nilavarta lugens) in Glutinous rice Warp varieties. This research was conducted on November until January 2016 at the BPP (Agency for Agricultural Extension) Binong Village, Binong Subang District. Daily average temperature of 28-30 O C, with a height of $43 \mathrm{~m}$ above sea level. This research used experimental one factor design and completely randomized design (CRD) and three replications and treatments, respecting $\mathrm{A}=0.50 \mathrm{ml} \mathrm{l-1}$, treatment $\mathrm{B}=1.00 \mathrm{ml} 1-1$, Treatment $\mathrm{C}=1.50 \mathrm{ml} \mathrm{1-1}$, treatment $\mathrm{D}=2.00 \mathrm{ml} \mathrm{l}-1$, treatment $\mathrm{E}=2.50 \mathrm{ml} \mathrm{1-1}$, treatment $\mathrm{F} 3.00 \mathrm{ml} \mathrm{l}-1$, treatment $\mathrm{G}=3.50 \mathrm{ml} \mathrm{l}-1$, treatment $\mathrm{H}=4,00 \mathrm{ml} 1-1$ treatment I $=4,50 \mathrm{ml} 1-1$, treatment $\mathrm{J}=$ control. Post harvest test used was DMRT (Duncan Multiple Range Test) at $5 \%$ level. The Parameters of this study are Including the percentage of mortality observations of broen planthopper, Brown Planthopper Number of living, due to the intensity of the attack Brown Planthopper Trunk, and plant height. The results showed that the use of insecticides Imidakloropid and BPMC effect on mortality Brown Plant hopper Trunk with the best concentration at 3, 5 ml-1.
\end{abstract}

Keywords: Brown planthopper (BPH), glutinous rice, insecticide imidacloprid with BPMC.

\section{Introduction}

Rice is a strategic commodity and the main food source for the people of Indonesia. The Government of Indonesia from 1960 until now has always tried to maintain and increase the production of these commodities (Rismunandar, 1993; Subandi, Eri Mustari,\& Ari, 2018). Indonesia has various types of rice with their respective colors and one of them is white glutinous rice. White glutinous rice has a white that is not transparent and almost all of its starch is amylopectin.

White glutinous rice used to be consumed interrupted in white glutinous rice can also be used as a mask for this sticky rice contains vitamins B12, B1 and vitamin $\mathrm{E}$ that has been proven to be good for skin health and beauty. White glutinous rice also contained some superior varieties, and one varieties. The white sticky rice of warp varieties has the potential yield of 6,0 ha- 1 with a weight of 28 grams $1000-1$ grains (Haerudin, 2015). 
The carbohydrate content of glutinous rice is very high compared to protein, fat and vitamins causing carbohydrates to have an important role in determining the characteristics of food ingredients, such as taste, color, texture and others. Starch which is found in glutinous rice contains very high A milopectin, 99,7\% and is non-expanding in cold water (Kadan et al., 1997; Subandi, Dikayani, \& Firmansyah. 2018).

Weed is an unwanted plant but can be used as a source of compost fertilizer. By utilizing weeds as a source of organic material, as well as sources of N, P and K, it can reduce the use of artificial pesticide (Frasetya,et al., (2019) Fertilizers. Besides that weeds are renewable natural resources that do not pollute the environment, while Urea, Phosphorus and $\mathrm{KCl}$ are not updated and tend to pollute the environment.

Pest of sucking cell solution may cause much damage in plant (Subandi et al 2017); Stems brown plant hopper (BPH) damage rice plants by sucking fluids rice plant stem cells, so that plant growth is inhibited and if the population is high can cause rice plants die of drought or look like burns (hopperburn). Besides that WBC also functions as a vector of dwarf grass and dwarf virus (Mochida, 1978).

The high level of WBC pest attack on rice plants causes the need for very effective control so that it can suppress the WBC population in rice plants, one of which is using insecticides with an active mixture of BPMC (Buthyl Phenil Metil Carbamate) and imidacloropid. This BPMC is a non-systemic insecticide that works as a contact poison in pests, especially in WBC pests (Djojosumarto, 2008), while imidacloropids are active ingredients that can penetrate into plant tissues which are then channeled to an acropetal reaction by plants (Dewar, 1992). This insecticide has been widely applied by farmers in the field but imidacloropid and BPMC insecticides are applied at inappropriate concentrations so that it has the potential to increase resistance to these pests.

The results of the study conducted by Baehaki (2011) used insecticides with active imidacloropid and BPMC laboratory methods on IR74 variets and Hipa 4 with doses of 0, 51 ha -1 and 1.51 ha -1 , and 0.251 ha -1 against WBC biotypes 4 G1 and G2 are approximately $50 \%$. In the treatment of Imidacloprid and Deltamethrin separated in the laboratory against brown planthopper biotypes $1 \mathrm{G} 1$ respectively $99,8 \%$ and 50.6\%. At 75 DAP, IR74 and Ciherang varieties reduced the brown planthopper population by $52.3 \%$ and $66.1 \%$, while Hipa 4 still did not reduce the brown planthopper population. The decrease in the population of brown plant hopper by imidacloprid insecticide ranged from 20.1-52.4\%, a decrease by low BPMC insecticides, 9.2-26.4\%. Based on the above considerations, it is necessary to study the Effectiveness Test of BPMC and Imidacloropid Active Ingredients on the Rod Brown (WBC) Slope Pests in the Glutinous Rice of Lusi Varieties.

\section{Material and Methods}

The research was conducted from November to August 2016 at the BPP (Agricultural Extension Agency) office in Binong Village, Binong Subdistrict, Subang Regency with a place height of $43 \mathrm{~m}$ above sea level with a moderate climate type C (BB. Padi, 2014). The materials used in this study are as follows: Ketan Lusi varieties of rice seeds, Insecticides (Active Ingredients: imidacloropid $100 \mathrm{gl}-1$ + BPMC $300 \mathrm{gl}-1$ ), Brown and Water Stem Marbles pests. 
The study used a one-factor Completely Randomized Design (CRD) with ten replications. The treatment used is Wingr eat 400 EC insecticide (BPMC Active Ingredient with Imidacloropid)

a. The active ingredient of BPMC mixture with Imidacloropid concentration $(0.5 \mathrm{ml} 1-1)$

b. The active ingredient of BPMC mixture with Imidacloropid concentration (1.0ml $1-1)$

c. The active ingredient of BPMC mixture with Imidacloropid concentration (1.5ml $1-1)$

d. The active ingredient of BPMC mixture with Imidacloropid concentration (2.0ml $1-1)$

e. The active ingredient of BPMC mixture with Imidacloropid concentration $(2.5 \mathrm{ml} 1-1)$

f. The active ingredient of BPMC mixture with Imidacloropid concentration (3.0 $\mathrm{ml} 1-1)$

g. The active ingredient of BPMC mixture with Imidacloropid concentration $(3.5 \mathrm{ml} 1-1)$

$\mathrm{h}$. The active ingredient of BPMC mixture with Imidacloropid concentration (4.0 $\mathrm{ml} 1-1)$

i. The active ingredient of BPMC mixture with Imidacloropid concentration (4.5ml $1-1)$ Without insecticide

\section{Results and Discussions}

The result of observation of temperature during the study, the minimum temperature reached $230 \mathrm{C}$ and the maximum temperature reached $36 \mathrm{oC}$ and the average humidity was 48 $\%-95 \%$.

\subsection{Percentage of Brown Bar Slope Mortalityon Rice (\%)}

WBC mortality observation is done by calculating the number of WBC observed, divided by the number of WBCs that live then multiplied by $100 \%$. From some observations no mortality was found such as at lowconcentrations and without using insecticides, the average observations are presented in Table 1.

Table 1. Average Effect of Imidaloropid And BPMC Insecticides on WBC Mortality Percentage

\begin{tabular}{ccccc}
\hline \multirow{2}{*}{ Treatment } & \multicolumn{4}{c}{ WBC\% Mortality } \\
\cline { 2 - 5 } & $23 \mathrm{DAP}$ & $24 \mathrm{DAP}$ & $25 \mathrm{DAP}$ & $29 \mathrm{DAP}$ \\
\hline $\mathrm{A}$ & $0.00 \mathrm{a}$ & $0.00 \mathrm{a}$ & $0.00 \mathrm{a}$ & $0.00 \mathrm{a}$ \\
$\mathrm{B}$ & $0.00 \mathrm{a}$ & $0.00 \mathrm{a}$ & $0.00 \mathrm{a}$ & $0.00 \mathrm{a}$ \\
$\mathrm{C}$ & $0.00 \mathrm{a}$ & $0.00 \mathrm{a}$ & $0.00 \mathrm{a}$ & $0.00 \mathrm{a}$ \\
$\mathrm{D}$ & $3.33 \mathrm{a}$ & $0.00 \mathrm{a}$ & $0.00 \mathrm{a}$ & $10.00 \mathrm{c}$ \\
$\mathrm{E}$ & $0.00 \mathrm{a}$ & $3.33 \mathrm{a}$ & $3.33 \mathrm{a}$ & $10.00 \mathrm{c}$ \\
$\mathrm{F}$ & $6.66 \mathrm{a}$ & $13.33 \mathrm{~b}$ & $23.33 \mathrm{bc}$ & $3.33 \mathrm{ab}$ \\
$\mathrm{G}$ & $26.66 \mathrm{a}$ & $13.33 \mathrm{~b}$ & $13.33 \mathrm{bc}$ & $10.00 \mathrm{c}$ \\
$\mathrm{H}$ & $40.00 \mathrm{~b}$ & $30.00 \mathrm{c}$ & $26.66 \mathrm{c}$ & $6.66 \mathrm{bc}$ \\
$\mathrm{I}$ & $43.33 \mathrm{~b}$ & $40.00 \mathrm{c}$ & $16.66 \mathrm{bc}$ & $3.33 \mathrm{ab}$ \\
$\mathrm{J}$ & $0.00 \mathrm{a}$ & $0.00 \mathrm{a}$ & $0.00 \mathrm{a}$ & $0.00 \mathrm{a}$ \\
\hline
\end{tabular}

Description: The numbers followed by the same letter notation in the same column show no significant difference based on Duncan's advanced test at the level of $5 \%$ 
Based on observations, it can be seen that the average value presented in Table 2 shows that there are significant differences in each observation, observing 23DAP, 24DAP, 25DAP and 29DAP the number of mortality is found in treatments F, G, H and I because of the high concentration Much mortality was found in this treatment due to the rapid extermination of insecticides at high concentrations, but the use of insecticides that were too high could cause damage to the surrounding environment including the survival of natural enemies of the WBC.

According to a statement from Baehaki (2011), insecticides with active ingredients of imidacloropids and BPMC separately are recommended to be used at concentrations of 2.0$4.0 \mathrm{ml} 1-1$ and applied at 8-11, the morning is continued in the afternoon. In the seven observations, no WBC mortality was found in the absence of mortality in the J treatment, without the application of insecticides, the plant continued to be used as a habitat for WBC until the seventh observation was carried out on plants aged 41DAP.

According to Erwin (2009) statement, the use of Imidacloropid insecticide active ingredients combined with BPMC in plants greatly influences mortality rates in insects At the observations of 33DAP, 37DAP and 41DAP the number of WBC mortality was not present in treatment A, B, C, because in treatment A the concentration was $0.5 \mathrm{ml} \mathrm{1-1}$, silver B $1.0 \mathrm{ml} 1$ 1 and treatment $\mathrm{C} 1.5 \mathrm{ml} \mathrm{l}-1$. The concentration used when spraying applications is very small and there is no effect at all on the survival of the $\mathrm{WBC}$, WBC remains alive even though spraying has been carried out but at E, F, G, H mortality occurs at 33 DAP, 37 DAP, 41 DAP use of insecticide concentration the small one can kill the WBC but in the process and for a long period of time compared to the use of large concentrations.

According to a statement from Altman (1991) Imidacloropid insecticides are chemical compounds that can control insects with a good system and this significant activity is due to the imidacloropids having a systemic work system. The action of this imidaclorpid is by taking action with the influence of inphus delivery in the nervous system on WBC insects, by sending it naturally to the ecetycholine, acting due to the presence of something that has nerve cells to work in a cell that is less sensitive to protein stimulation ( Leicht, 1996).

According to Sutrisno's statement (2014) insecticides that differ in groups and how they work can be applied rotationally to inhibit resistance. Inhibition of development resistance can occur because before developing into a WBC population resistant to a class of insecticides, the population has been treated with other groups of insecticides that are different ways of working. For example, carbamate class insecticides, rotated with phenylpirazoleinsecticides, or insect growth regulator groups, or nicotinoid groups. This method can be applied by farmers, if farmers are aware of the importance of insecticide rotation and the availability of various groups of insectides in the market at reasonable prices and affordable by farmers.

\subsection{The Amount of Live Brown Barrel (Tail)}

Observations are carried out at intervals 25DAP, 29DAP, 33DAP, 37DAP. 
Table 2 . Average Effect of Giving Imidacloropid and BPMC Insecticides on the Number of Living WBC

\begin{tabular}{ccccc}
\hline Treatment & WBC H-1 & WBC H-2 & WBC H-3 & WBC H-4 \\
& 25 DAP & $29 D A P$ & $33 D A P$ & $37 D A P$ \\
\hline A & $10.00 \mathrm{c}$ & $16.66 \mathrm{e}$ & $10.00 \mathrm{e}$ & $10.00 \mathrm{e}$ \\
B & $10.00 \mathrm{c}$ & $16.66 \mathrm{e}$ & $10.00 \mathrm{e}$ & $10.00 \mathrm{e}$ \\
C & $10.00 \mathrm{c}$ & $16.66 \mathrm{e}$ & $10.00 \mathrm{e}$ & $10.00 \mathrm{e}$ \\
D & $9.66 \mathrm{c}$ & $14.66 \mathrm{de}$ & $7.66 \mathrm{~d}$ & $6.66 \mathrm{~d}$ \\
E & $9.33 \mathrm{c}$ & $14.00 \mathrm{~d}$ & $7.33 \mathrm{~d}$ & $6.00 \mathrm{~d}$ \\
F & $5.66 \mathrm{~b}$ & $8.33 \mathrm{c}$ & $4.33 \mathrm{c}$ & $3.66 \mathrm{c}$ \\
G & $4.66 \mathrm{~b}$ & $6.00 \mathrm{~b}$ & $3.00 \mathrm{~b}$ & $2.00 \mathrm{~b}$ \\
H & $0.66 \mathrm{a}$ & $0.00 \mathrm{a}$ & $0.00 \mathrm{a}$ & $0.00 \mathrm{a}$ \\
I & $0.33 \mathrm{a}$ & $0.00 \mathrm{a}$ & $0.00 \mathrm{a}$ & $0.00 \mathrm{a}$ \\
$\mathrm{J}$ & $10.00 \mathrm{c}$ & $16.66 \mathrm{e}$ & $10.00 \mathrm{e}$ & $10.00 \mathrm{e}$ \\
\hline
\end{tabular}

Description: The numbers followed by the same letter notation in the same column point the difference is not significantly based on Duncan's advanced test at the level of 5\%

The observations that have been made get the effect of real differences which can be seen in Table 3. Observations were made by calculating the amount of WBC that lives on each rice plant that is in captivity. Observation is by calculating the amount of mortality for each observer, at 25DAP, 29DAP, 33DAP, 37DAP. The effect of real differences was found in observations of A, B, C, D and J. In treatment A the concentrations used were $(0.50 \mathrm{ml}-1)$, B $(1.00 \mathrm{ml}-1), \mathrm{C}$ $(1.50 \mathrm{ml}-1)$ and in treatment $\mathrm{D}$ is $(2.00 \mathrm{ml}-1)$, it can be seen that the insecticides in some treatments whose total WBC is intact do not experience mortality. In the treatment given insecticides with small concentrations the reaction to WBC mortality is slow or does not kill quickly as in high concentrations, but it is not recommended to use high concentrations of inorganic insecticides and must be selective in using them.

As stated by setiawan et all., (2004) The use of insecticides must be selective without disturbing gu against natural enemies can be done by way of(1) the use of selective insecticides with minimal concentration, (2) the use of insecticides in the area / place of planting is limited, namely where the explosion of pests occurs, (3) the use of poisonous bait, and (4) the application of insecticides based on the threshold for controlling target pests. Some types of insecticides are known to be selective against natural enemies.

In observing J treatment (control) without the application of WBC insecticides, it remained free in confinement due to plants which were not first given resistance to insecticide except for plants that did have resistance to WBC but in the use of even small concentrations the WBC did not experience mortality. The difference in the resistance of rice varieties to brown plant hopper is suspected because of the mechanism of antibiosis which is one element of the content of chemical compounds in the form of toxins that can inhibit the growth and development of pest insects. 
This is in line with the opinion of Astuti (2009 ; Subandi et al., 2017 ) which states that plant resistance can be in the form of antibiosis, ie plants produce toxins that can kill or inhibit the growth of pests. Antibiosis is a plant characteristic that adversely affects insect life. Antibiosis is caused by the presence of chemicals which are toxic repellents, certain nutrients that are not available to insects and differences in the quantity of nutrients. Antiobiosis found in rice plants is oxalic acid.

Oxalic acid known to interfere with the process of eating chocolate bars planthopper in rice by inhibiting the process of sucking the phloem. Oxalic acid is an important factor that controls the resistance of rice plants to brown plant hopper. This substance affects the metabolism and protein synthesis in the body of insects (Yoshihara et al., 1980). Oxalate can be in the form of soluble oxalte and insoluble oxalate (Akhtar et al., 2011).

The dissolved oxalate oxalic acid and oxalate form insoluble calcium oxalate crystals can form (Franchesi and Nakata, 2005). In angiosperm plants, oxalate in the form of oxalic acid and calcium oxalate crystals, are stored in the cell vacuole (Muji, 2013).

On the observation of the number of living WBC, the lowest percentage value for each treatment is in treatments $\mathrm{H}$ and $\mathrm{I}$, namely in treatment $\mathrm{H}$ using a concentration of $4.00 \mathrm{ml}-1$ while in treatment I using a concentration of $4.50 \mathrm{ml}-1$ but at high concentrations it is not recommended because using high concentrations feared the resistance of WBC pests to glutinous rice plants. Because in using smaller concentrations as in treatment $\mathrm{G} 3.50 \mathrm{ml} \mathrm{WBC}$ pests have experienced mortality and WBC which live in fewer confinement.

\subsection{WBC Attack Intensity}

The intensity of the WBC attack is the percentage of the number of leaves attacked by pests from the total leaves observed. Observation The intensity of this WBC attack is carried out at 10-day intervals carried out at 41 DAP, 51 DAP and 61 HDAP. Processed with a variety of analysis methods (Analysis of Variance, ANOVA) and differences between treatments using Duncan's Multiple Range Test (Duncan Multiple Range Test). 
Table 3. Effect of Imidacloropid and BPMC insecticides on WBC Attack Intensity

\begin{tabular}{cccc}
\hline P & 41 DAP & 51 DAP & 61 DAP \\
\hline A & $2.32 \mathrm{e}$ & $9.56 \mathrm{de}$ & $11.72 \mathrm{ef}$ \\
B & $2.39 \mathrm{f}$ & $9.26 \mathrm{de}$ & $16.05 \mathrm{fg}$ \\
C & $2.57 \mathrm{f}$ & $11.72 \mathrm{e}$ & $19.44 \mathrm{~g}$ \\
D & $1.59 \mathrm{bc}$ & $2.16 \mathrm{~b}$ & $4.94 \mathrm{bc}$ \\
E & $1.61 \mathrm{~cd}$ & $4.01 \mathrm{bc}$ & $7.40 \mathrm{~cd}$ \\
F & $1.06 \mathrm{de}$ & $4.64 \mathrm{~cd}$ & $8.64 \mathrm{de}$ \\
G & $0.55 \mathrm{~b}$ & $1.35 \mathrm{~b}$ & $3.7 \mathrm{~b}$ \\
H & $0.00 \mathrm{a}$ & $0.00 \mathrm{a}$ & $0.00 \mathrm{a}$ \\
I & $0.00 \mathrm{a}$ & $0.00 \mathrm{a}$ & $0.00 \mathrm{a}$ \\
$\mathrm{J}$ & $2.32 \mathrm{e}$ & $9.37 \mathrm{de}$ & $11.71 \mathrm{ef}$ \\
\hline
\end{tabular}

Description: The numbers followed by the same letter notation in the same column show no significant difference based on Duncan's advanced test at the level of 5\%

In treatment $\mathrm{G}$ with concentrations $(3.5 \mathrm{ml}-1), \mathrm{H}(4.0 \mathrm{ml})$ and $\mathrm{I}(4.50)$ in the treatment of $\mathrm{H}$ and I attacks are low, in the observation of 41DAP and observation of 61DAP According to Baehaki's statement (2011) that in some studies insecticides recommended by active ingredients buprofezin, BPMC, fipronil and imidacloropid with concentrations recommended for appropriate insecticides with 400 to 500air ha -1 . The use of BPMC insecticide application concentration is recommended at a concentration of $2.5-3 \mathrm{ml}-1$ with a spray volume of around $500 \mathrm{~L}$ ha -1 . but the application is carried out if the population or intensity of pest attacks has reached the threshold of its control, in accordance with the regulations or requirements set by the authorities.

According to the statement of Soejitno et al., (2002) the intensity of attacks or damage caused by the WBC to rice plants was used as the basis for assessing the resistance of varieties. Assessment of damage to rice varieties was carried out at two stages of rice growth, namely at the age of 20 days or nursery. The WBC has a high birth rate while the mortality rate is low. So that the intrinsic growth rate is rapidly increasing.

Based on Table 4, there was a markedly different effect of attacks on observations to 51DAP, seen from treatment A $(0.5 \mathrm{ml}-1)$, on treatment $\mathrm{B}(1.0 \mathrm{ml}-1)$, on treatment $\mathrm{C}(1.5 \mathrm{ml}-$ 1) and treatment $J$ without using an insecticide which shows the intensity of the WBC attack at 51DAP. This is because the treatment $\mathrm{F}(3.0 \mathrm{ml} \mathrm{L}-1)$ has a lower concentration of imidacloropid and BPMC compared to treatment $\mathrm{G}(3.5 \mathrm{ml} \mathrm{L}-1)$

According to Baehaki (2011); and .Subandi, Dikayani, Firmansyah. (2018) said pids and BPMC can reduce the intensity of pest attacks because Imidacloropids and BPMC have the ability to control WBC pest attacks. Observation The intensity of the WBC attack at the age of 51 DAP there was a significant difference in treatment $\mathrm{E}$, and $\mathrm{F}$. In rice aged 51 DAP rice was increasingly attacked by WBC because the age of rice plants was getting older. 
Imidacloropids are very suitable for controlling sucking and piercing insects such as WBC. While the workings of BPMC, namely nerve toxins by working to inhibit cholin esterase if the organophosphate is a barrier that can not be restored while the carbamate barriers can be restored. Insecticides from carbamate groups are more easily broken down in the environment and not persistent (Panut, 2008; Subandi, Abdelwahab Mahmoud and Cecep T. (2019).

In observing the age of $61 \mathrm{DAP}$, the WBC attack was higher in each treatment due to the increasing number of brown plant hopper populations in the planting area. Control should be carried out on the 1st generation (G1) by re-spraying insecticides, but in the research no spraying was carried out again, so that the number of WBCs increased. According to (Soejitno ., Et al . 1987) the control will not be effective if the G3 WBC is left alive, because it will cause an attack to increase the voidness, reduce the grain blocking the filling of grains and will kill the plant so that the puso. The final result of the WBC attack is to reduce unity hectares of rice yields. The brown planthopper status that plays a role in puso is nymphs and imago.

\subsection{Plant height}

Plant height is a plant size that is often observed as an indicator of growth. Plant height is influenced by environmental factors, can be influenced by light, plant distance, fertilization, and can also be caused by pests. The height of the plant is very sensitive to light, plants that lack light are usually higher than plants that get enough light (Sitompul And Guritno, 1995).

Table 4. Effect of Giving BPMC And Imidacloropid Insecticides on Plant Height

\begin{tabular}{ccc}
\hline Treatment & High & High \\
& Plant 1 & Plant 2 \\
& $17 D A P$ & 31 DAP \\
\hline A $\left(0.5 \mathrm{ml}^{-1}\right)$ & $32.92 \mathrm{a}$ & $85.86 \mathrm{a}$ \\
B $\left(1.0 \mathrm{ml}^{-1}\right)$ & $33.46 \mathrm{a}$ & $86.76 \mathrm{a}$ \\
C $\left(1.5 \mathrm{ml}^{-1}\right)$ & $33.5 \mathrm{a}$ & $84.53 \mathrm{a}$ \\
D $\left(2.0 \mathrm{ml}^{-1}\right)$ & $32.6 \mathrm{a}$ & $97.8 \mathrm{~d}$ \\
E $\left(2.5 \mathrm{ml}^{-1}\right)$ & $33.43 \mathrm{a}$ & $95.6 \mathrm{~cd}$ \\
F $\left(3.0 \mathrm{ml}^{-1}\right)$ & $32.8 \mathrm{a}$ & $91.46 \mathrm{abc}$ \\
$\mathrm{G}\left(3.5 \mathrm{ml}^{-1}\right)$ & $33.66 \mathrm{a}$ & $97.16 \mathrm{~cd}$ \\
$\mathrm{H}\left(4.0 \mathrm{ml}^{-1}\right)$ & $33.93 \mathrm{a}$ & $93.5 \mathrm{bcd}$ \\
$\mathrm{I}\left(4.5 \mathrm{ml}^{-1}\right)$ & $33.6 \mathrm{a}$ & $87.66 \mathrm{ab}$ \\
$\mathrm{J}\left(1.5 \mathrm{ml}^{-1}\right)$ & $33.86 \mathrm{a}$ & $89.3 \mathrm{ab}$ \\
\hline
\end{tabular}

Description: The numbers followed by the same letter notation in the same column show no significant difference based on Duncan's advanced test at the level of $5 \%$ 
At the first observation carried out at 17 DAP before WBC was invested, no significant difference in effect was caused by spraying intervals aimed at increasing the toxicity of insecticides, not affecting plant growth and growing uniformly. If the plants grow uniformly and there are no plants that grow with dwarfs, the plants grow well and are not affected by the grass dwarf virus transmitted by the WBC. This can be seen at the time the research was carried out the plants had been given imidacloropid insecticides and BPMC in the initial vegetative phase. And when observing the plant has been in a tight hood, the plants are not exposed to any pests before being infected with the WBC (Soejitno et all. , 198 Frasetya, B., Harisman, K., Sudrajat, D. \& Subandi, M. (2019). Utilization of rice husk silicate extract to improve the productivity of paddy Ciherang cultivar. Bulgarian Journal of Agricultural Science, 25(3), 4995057).

In the second observation, the effect of real differences on plant height showed that the imidacloropid and BPMC insecticides did not inhibit plant growth because imidacloropids included insecticides in the chloronotyl sub-class. This imydacloropid systemic and translaminarini insecticide works as a contact poison and stomach poison which is absorbed by leaves and roots and transformed. Whereas carbamate insecticides are neurotoxic insecticides that work by inhibiting choline esterase (Che). BPMC insecticides or pesticides from carbamate groups are relatively easy to decompose in the environment (not persistent) and do not accumulate by animal fat tissue (Panut, 2008).

\section{Conclusion and Suggestion}

\subsection{Conclusion}

Based on the results of the research that has been carried out it can be concluded as follows:

1. There is an effect of the concentration of insecticides of active ingredients BPMC and Imidacloropil on mortality, WBC live, the intensity of attacks of Batang Coklat (WBC) Waders ( Nilavarta lugens ) on glutinous rice varieties Lusi.

2. At concentrations of $3.5 \mathrm{~mL}-1$ the use of insecticides affected WBC mortality, WBC number, plant height, intensity of WBC attacks, plant height.

\subsection{Suggestion}

The suggestion that the writer can convey is that there is a need for further research on the effectiveness test of the active ingredient of butyl phenyl methyl carbamate (BPMC ) and imidacloropidinsecticides in rice glutinous warp varieties against natural enemies, environmental pollution and food safety.

\section{References}

[1] Altman, RD. 1991. Criteria for Clasification of Clinical Osteoarthtritis. Jurnal of Rheumatology. Vol 18 (27): 10-15

[2] Astuti, NP 2009. Organoleptic properties of soybean tempeh wrapped in banana leaves and Surakarta teak leaves: health science faculty, Muhammadiyah University. 
[3] Baehaki SE, Arifin K, and D. Munawar. 2011. The Role of Resistant Varieties in Reducing Biotype 4 Brown Planthopper Population in Rice Plants. Center for Rice Research. Food Crop Agriculture Research Vol. 30 No. 32011 .

[4] Erwin and T Sabrina. 2009. Capside of very harmful tobacco pests. Deli Tobacco Research Center. PTPN II, Medan

[5] Francessi, VR and Nakata, PA. 2005. Calcium Oxalate In Plant: Formation and Function Annual Review Of Biology Plant S6: 41-71.

[6] Frasetya, B., Harisman, K., Sudrajat, D. \& Subandi, M. (2019). Utilization of rice husk silicate extract to improve the productivity of paddy Ciherang cultivar. Bulgarian Journal of Agricultural Science, 25(3), 499-505

[7] Kadan, RS, Champagne, ET, Ziegler, GM \& Richard. AO 1997. Amylose and protein contents of rice cultivars are related to texture of rice-based fries. Journal of Food Science 62 (4): 701-703.

[8] Leicht PN. 1996. Spatial Pattern Of Mycorrhizal Infection Of Soil Long A Successional Chronosequence. 6: 79-90.

[9] Mochida, O. 1978. Brown Planthopper "Wereng Pests" Problems On Rice Indonesia. Cooperative CRIA-IRRI Sukamandi, West Java, Indonesia Program. 70 things.

[10] Muji. 2013. The distribution of calcium oxsalate cristal reduction of oxalltaete and the effect of cultivation method on its formation in some vegetebles. Department of Biology Education, Kediri: PGRI archipelago university.

[11] Rismunandar. 1993. Pests of Food Plants and Their Basics. Bandung: publisher of Sinar Baru.

[12] Setiawan , Guntur. 2004. Implementation in Agricultural Development. Bandung: Teenager Rosdakarya .

[13] Soejitno. J. 2002. Pestcide Residue On Fod Crops And Vegetables In Indonesia. Indonesia. 132 Agric. Res. Dev. J. 21 (4): 124.

[14] Subandi, M, Dikayani, E Firmansyah. 2018 . The production of reserpine of Rauwolfia serpentina (L) kurz ex benth through in vitro culture enriched with plant growth regulators of NAA and kinetin.International Journal of Engineering \& Technology 7 (2.29), 274-278.

[15] Subandi, M, Eri Mustari, Ari S. 2018 . The Crossing Effect of Dragon Fruit Plant Caltivars (Hylocereus Sp.) On Yield. International Journal of Engineering \& Technology 7 (2 , 29 ), 762-765.

[16] Subandi, M., Y. Setiati, NH Mutmainah. 2017. Suitability of Corcyra cephalonica eggs parasitized with Trichogramma japonicum as intermediate host against sugarcane borer Chilo auricilius. Bulgarian Journal of Agricultural Science. 23 (5). 779-786

[17] Subandi, M., Abdelwahab M. Mahmoud and Cecep T. (2019). A review of Egyptian afforestation program and its effect on agriculture. Asian Journal of Agriculture and Rural Development, 9(1), 1-18. [18] Sutrisno. 2014. Rod Brown rice planthopper resistance Nilaparvata lugens Stal to Insecticides in Indonesia. Agro Biogen Journal Vol. 10 No. (3). Page 115-124. 